\title{
Akerprosjektet: Én pluss én blir noen ganger mer enn to!
}

\author{
Kirsti $\mathrm{H}$ afnor intervjues av Dag W illy Tallaksen
}

En godt organisert behandlingskjede for mennesker som har gjort forsøk på å ta sitt liv, er viktig for å sikre adekvat oppfølging i den første tiden etter selumordsforsøket. Ved å utnytte allerede eksisterende ressurser kan resultatet bli svaert utbytterikt både for den hjelptrengende og hjelperne. Aker sykehus i Oslo har valgt å gå egne veier ved etablering av behandlingskjede.

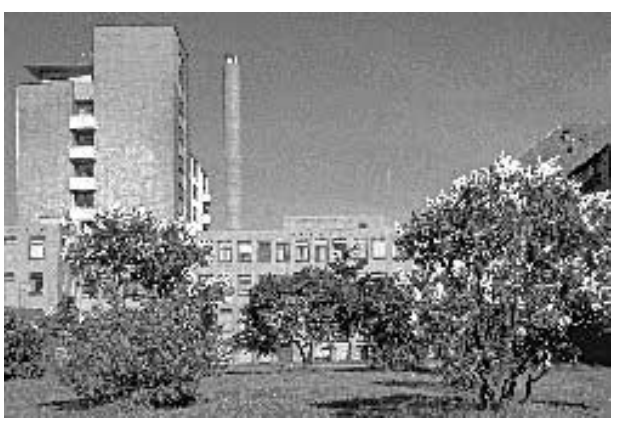

A ker sykehus

Det finnes i dag flere eksempler på hvordan man kan organisere behandlingskjeder for mennesker som har gjort selvmordsforsøk. Den eldste og trolig mest kjente er Bærumsmodellen (etablert i 1983).

I denne behandlingskjeden blir alle som kommer til sykehusets mottakel sesavdeling etter et selvmordsforsøk, kontaktet av en representant for sosionomtjenesten ved sykehuset. Derfra blir det gitt melding til hel sesøstertjenesten i pasientens hjemkommune om at vedkommen de har vært innlagt etter forsøk på å ta sitt liv ( se Suicidologi nr. 1/97, s. 9-10). En forutsetning er at pasienten ikke motsetter seg at slik melding gis. R epresentanter for hel sesøstrene føl ger så opp med tanke på videre behov for hjelp.

I forrige nummer av Suicidologi ble prosjektet "Tiltak mot selvmord - Buskerud" presentert. Sentralt i denne modellen står prinsippet om at det i alle aktuelle sykehusavdelinger og i alle lokalkommuner skal finnes en fagperson som er ansvarlig for første kontakt og for å hjelpe til med nødvendig oppfølging av mennesker som har forsøkt å ta sitt liv. U t over landet er det prøvd ut andre modeller som har ført til mer eller mindre permanente behandlingskjeder for å fange opp mennesker i selvmordskrise. Statens hel setilsyn vil om kort tid komme med en utredning om innføring av rutiner for oppfølging av mennesker etter selvmordforsøk.

I O slo kommune har bydelene som sogner til A ker sykehus gått sammen om å etablere en behandlingskjede som foreløpig går under navnet A kerprosjektet (omtalt i Suicidologi nr. 1/98, s. 21-22). Sentralt i dette prosjektet er etablering og vedlikehold av "ombudsteamet". M edlemmene i ombudsteamet består av sykepleiere i mottakelsesavdelingen på sykehuset, og av psykiatiske sykepleiere fra hjemmetjenesten i hver av de 7 bydelene i A ker sektor. A lle som kommer til sykehuset etter et selvmordsforsøk, blir tilbudt psykiatrisk vurdering. Denne foretas av psykiater eller psykiatrisk sykepleier fra Konsultasjonspsykiatrisk avdeling. Så raskt som mulig blir det gitt melding til ombudet i den bydelen pasienten bor, om at vedkommende er eller har vært innlagt. Et annet viktig poeng i denne modellen er at alle medlemmene i ombudsteamet tilbys systematisk veiledning en gang pr. uke. Denne ukentlige samlingen alternerer mellom en mer pasientfokusert veiledning gitt av konsultasjonsspsykiater, og den mer personellfokuserte ledet av høgskolelektor i psykiatrisk sykepleie.

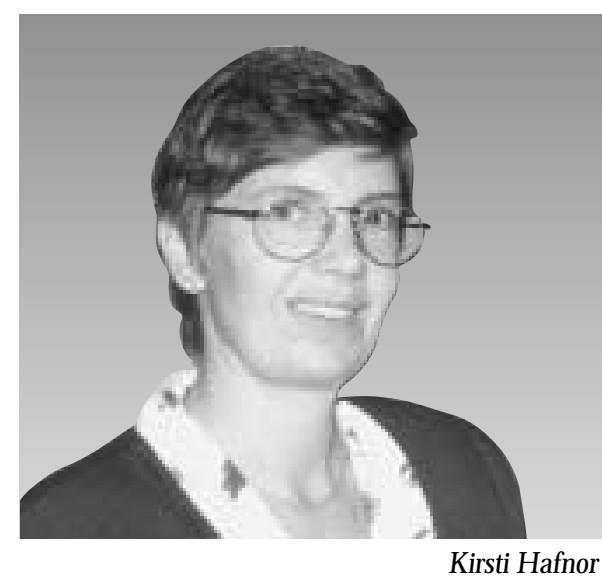

Bare et drøyt steinkast fra A ker sykehus finner vi ombudet for bydelen H elsfyrSinsen, Kirsti H afnor. Kanskje er det symptomatisk for medarbeiderne i ombudsteamet at avtaler ordnes raskt? D et gikk i alle fall ikke mer enn et par dager fra undertegnede på vegne av tidsskriftet Suicidologi ba om et intervju til jeg satt i en stol pâ hennes kontor med nytrukket kaffe i den ene hånda og blyant i den andre. $\mathrm{H}$ afnor kan sies å være en av veteranene i prosjektet, i og med at hun har vært med siden januar 1998. Prosjektet startet i 1997 med kurs for alle som var inkludert i det nye ombudsteamet. $\mathrm{H}$ un forteller at det den gang var rift om å få bli med fra bydelen, det var flere som gjerne ville delta i prosjektet. Det er etablert ombud i åtte bydeler, og hvert ombud har $20 \%$ av sin stilling øremerket til arbeidet med oppfølgingen av mennesker som har forsøkt å ta sitt liv. A ker sektor dekker en befolkning på ca. 130000 mennesker. På spørsmål om dette er en dekkende stillingsbrøk, så er svaret at det i det store er tilstrekkelig, men det kan tidvis være hektisk dersom flere pasienter med selvmordstanker blir henvist samtidig.

\section{H vordan vil du beskrive fremgangs- måten i arbeidet med de menneskene dere får henvist?}

- Det er viktig for oss å etablere kontakt med pasienten så raskt som mulig, slik at den enkelte skal slippe å være al ene eller føle seg overlatt til seg selv med sine selvmordstanker. Det medfører at den første kontakt ofte etableres før det er kommet noe notat fra sykehuset. (C a. $90 \%$ av henvisningene kommer fra A ker sykehus, noen ganske få henvisninger kommer fra primærleger og Legevakten.) Det hele starter med en tel efonsamtale. Denne samtalen brukestil å innhente nødvendig praktisk informasjon og å finne ut om første møte skal skje i pasientens hjem eller på sykepleiers kontor. H elst vil jeg ha det første møtet i løpet av 2-3 dager og helst i pasientens hjem. A gjennomføre møtet i pasientens hjem gir en rekke tilleggsopplysninger om hvordan pasienten bor, hvem han/hun bor sammen med, og hvordan boligen og dagliglivet ser ut etc. I det hele tatt gir hjemmebesøk mulighet for å danne seg et hel hetsbilde av den enkelte og hans/hennes livssituasjon. Jeg setter alltid av god tid til dette møtet, i praksis viser det seg at halvannen time er tilstrekkelig. H er ligger en viktig begrensning; ansvaret for den enkeltes liv skal fortsatt ligge hos pasienten. Den videre innhentingen av informasjon om selvmordsforsøket/tankene skjer ut fra et 
standardskjema som alle i ombudsteamet benytter. Den første samtalen vil jeg ha med pasienten alene, men det hender noen ganger at det ikke lar seg gjøre. $M$ ange pårørende har mye på hjertet, og at de får slippe til kan bidra til å utvide forståel sen. Pasienten selv må imidlertid alltid få komme frem med sitt. $M$ in erfaring fra hjemmesykepleien der jeg kom inn i mange hjem, og ikke minst den lokalkunnskap som fast og langvarig tilknytning til bydelen har gitt, benyttes til å vurdere hvor første samtale bør foregå. Samtaler som jeg aner kan få preg av krangel eller kan komme til å foregå i hjem der det $\mathrm{f}$. eks finnes aggressive hunder, vel ger jeg å legge til kontoret. Enkelte pasienter ønsker også å komme til mitt kontor. I løpet av det første møte får pasienten oppgitt telefonnummeret til sykepleieren/ombudet. Telefonen ringer i grunn ikke særlig mye, sier $\mathrm{H}$ afnor.

\section{H va er den videre gang $\mathrm{i}$ arbeidet?}

- Det består i å vurdere grad av suicidalitet og videre oppføl gingsbehov. C a. 3/4 av pasientene blir etter vurderingen henvist videre i behandlingsapparatet. D et kan være til primærlege, distriktspsykiatrisk senter (DPS), sosionomtjeneste, vernepleiertjeneste, hjemmetjeneste, psykiatrisk sykepleier og eldresenter med mer. Enkelte pasienter har det for vanskelig eller er for dårlige til at de kan bo hjemme. Lokalkunnskapen jeg har fra den andre delen av stillingen, som psykiatrisk sykepleier i bydelen, er uvurderlig, sier $\mathrm{H}$ afnor spontant.

Her får H afnor som ombud mye "gratis", fordi kontakten allerede er etablert med primærleger, bydel soverlege og det lokale DPS. 0 mbudene nyter en stor grad av legitimitet, og har derfor lett for â komme igjennom med sine ønsker om videre behandling både i og utenfor institusjon. Et felles trekk ved de yngste pasientene er at de ofte ikke har primærlege og de trenger hjelp til å skaffe seg det.

- Den siste fjerdedelen av pasientene blir fulgt opp av ombudet i kraft av hennes stilling (alle er jo også psykiatriske sykepleiere). D enne oppfølgingen skjer innen en tidsramme på tre måneder og dreier seg i giennomsnitt om fem til ti-tolv samtaler. M ottoet for disse timene kan sammenfattes slik: "Det dreier seg om å ha noen å snakke med, som ikke prater svada."
- Jeg legger også vekt på å unngå moralisme og formynderholdning, sier $\mathrm{H}$ afnor. Bare noen få pasienter kutter ut tilbudet og vil heller klare seg selv. De fleste er glade for at vi kommer i gang så raskt. $0 \mathrm{~g}$; - og dette er en utfordring med tanke på forebyggingsperspektivet, - de fleste er ikke klar over at det finnes et slikt tilbud om oppfølging av mennesker med selvmordstanker.

$0 \mathrm{~m}$ avslutningsfasen i samarbeidet med det selvmordstruede menneske sier $\mathrm{H}$ afnor:

- Jeg ser til at pasienten kommer på plass i livet sitt igjen, i skole, studier eller arbeid.

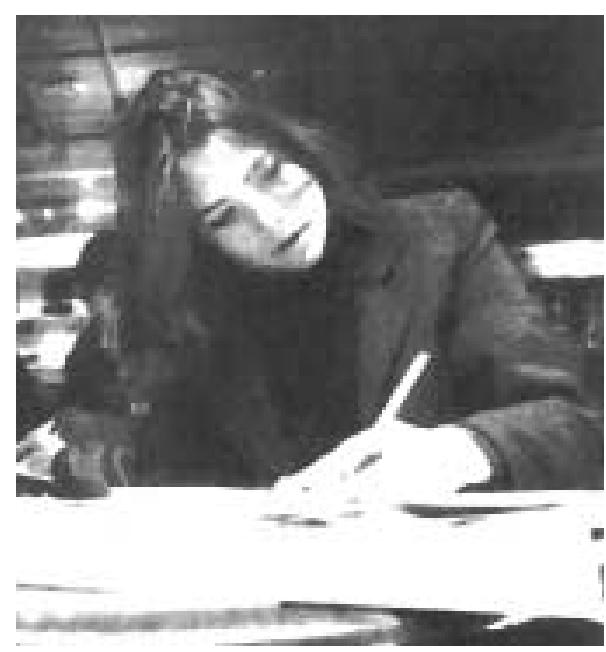

Bydel stilknytningen gjør at jeg ser pasientene igjen i deres daglige virke, ettersom jeg beveger meg mye rundt i lokal miljøene på vei til og fra mine andre oppgaver, og kan se at de i alle fall på overflaten ser ut til å fungere. Det gjør godt.

\section{Veiledning ligger inne som et tungt element i prosjektet, vil du utdype dette?}

- Veiledning er alfa og omega i prosjektet. For det første er den veiledning som gis av konsultasjonspsykiater, alltid mulig å relatere til den enkelte pasient, siden alle er vurdert av konsultasjonsavdelingen.

Det gir god mulighet for å være svært konkret. H er kan vi diskutere faglige vurderinger, behov for videre behandling, eventuelle sykdommer etc. I den sykepleiefagl ige delen går vi ikke i samme grad inn i den enkelte sak, men arbeider med egne reaksj oner. G ruppen er homogen, og vi kjenner igjen utfordringene som tas opp.
A lle medlemmene av ombudsteamet som arbeider i bydelene, er alene i sin bydel med dette arbeidsområdet. M øtene i veiledningsgruppen dekker behovet for faglig fellesskap. Veiledningen fungerer som et sikkerhetsnett både faglig og personlig. En positiv konsekvens av veiledningen er at den gir mulighet for å mestre store utfordringer uten opplevelse av å være alene. Den gir mulighet for å dele sine erfaringer med andre og den gir nye innfallsvinkler.

- H er må skytes inn, sier $\mathrm{H}$ afnor, at å dele i denne sammenheng også innbefatter at vi for eksempel i ferier tar over andre ombuds oppgaver. O rganiseringen sikrer at det alltid er mulig å få tak i et av ombudsteamets medlemmer. Jeg føler at veiledningen er et nødvendig gode, og jeg gleder meg til hvert møte.

Det var ikke dårlig fra en som er ansatt i en av 0 slo kommunes østlige bydeler. Skal vi tro massemedia, mangler disse bydelene det meste. M ed riktig organisering er det altså mulig å få behandlingskjeden til ikke bare å fungere, men fungere slik at de ansatte føler glede og overskudd. Det er til og med et område yrkesutøvere søker seg til. M ed en slik holdning til arbeidet er det grunn til å tro at brukerne eller pasientene også blir godt ivaretatt. Én pluss én kan under riktige forhold bli mer enn to!

\section{Finnes det ingen negative sider ved denne måten å organisere tjenesten på?}

J eg forsøker å peke på at deltakerne i teamet kun kommer fra sykepleiergruppen og derfor mangler det tverrfaglige element. M en nei...

-Vi kjenner hverandres yrkesbakgrunn. Likheten gjør at vi lett kan sette oss inn i de andres jobbutfordringer. I ombudsteamets etableringsperiode var det nok noe usikkerhet mellom oss og andre yrkesgrupper. N å vet vi hva vi og de samarbeiden de instanser står for, og det stillesikke lenger spørsmål ved organiseringen. Det må også legges til at prosjektet ledes av G eorg Schjelderup, som er psykiatrisk sykepleier/stipendiat ved Seksjon for selvmordsforskning og -forebygging. $\mathrm{H}$ an skriver sin avhandling knyttet til selvmordsforebyggende arbeid i A ker sektor. 